\title{
Local Wisdom of Repong Damar for Landslide Mitigation in Way Krui Sub-district Pesisir Barat Regency Lampung
}

\author{
Meri Herlina, Dewi Liesnoor Setyowati, Juhadi \\ meriherlina@6695@gmail.com¹,dewiliesnoorsetyowati@gmail.com², juhadigeo@mail.unnes.ac.id ${ }^{3}$ \\ Universitas Negeri Semarang, Indonesia
}

\begin{abstract}
Environmental problems are now becoming great issue and are the most frequent happened. Therefore, local wisdom plays an important role in protecting the environment, one of which is the local wisdom of Repong Damar as a form of landslide mitigation for the Way Krui society in the Pesisir Barat Regency, Lampung. The objectives of this study: to examine the local wisdom of Way Krui society in landslide mitigation; to explore the strategic adaptability of the Way Krui society in the facing a landslide. The approach of research uses a qualitative, the sampling technique snowball sampling, data collection techniques observation, interview and documentation. The validity of data uses triangulation. The result of the study: the local wisdom of the society to manage Repong Damar as a form of landslide mitigation is the existence of prohibited forests. So if the society destroys Repong Damar it is believed that it will be miserable and will get a bad disaster. The strategic adaptability that society does to keep Repong Damar stay sustainable.
\end{abstract}

Keywords: Local Wisdom, Mitigation, Landslide

\section{Introduction}

The environmental problems become a great issue because the environment is very influential for human life and the environmental problems turned out to be closely related to local wisdom. One of them is local wisdom of Repong Damar has been carried out by the community so that it still survives until now even though not all people run the customary law. Even though the sustainability of forest like Repong Damar management is very dependent on the participation of local communities in management ${ }^{[1]}$.

Landslide is one of the most common disasters in Pesisir Barat Regency, within a year that in 2017 there has been a landslide twice. Pesisir Barat Regency is an area that is included in the zone I and zone II, which is prone to catastrophic land movements such as landslides and soil erosion [2]. The danger of landslide has a great influence on the survival of human life and always threatens the safety of human beings [3].

The landslide that occurred in Way Krui Sub-district caused along the road is surrounded by mountains or cliffs so that when the heavy rains in a long time then there will be a landslide because the land can not resist the heat of the water. Landslides that occur cause casualties, property loss, and environmental damage [4]. So the disaster that resulted in thousands of casualties loss of property is not something good for human [5]. So it can be concluded that any disaster will surely inflict damage to human beings such as casualties and environmental damage and it is not a good impact on human beings. 
Landslides are movements of land mass from higher areas to lower areas. The danger of landslides such as other natural hazards, landslides can be characterized by their intensity such as the high intensity of rain [6]. The cause of landslides is the movement of land in unstable soil conditions which is often triggered by high rainfall [7].

Based on the disaster events and the condition of people in the disaster-prone described above, then efforts are needed in understanding and anticipating natural conditions in an integrated manner. One of its forms, through disaster risk reduction efforts is through local wisdom. This means that public awareness of efforts to reduce the risk of landslides is very important [8].

Local wisdom is an activity, knowledge, and belief of a society in managing nature that oriented to environmental sustainability. Local wisdom is formed as a process of interaction between humans and their environment in order to meet various needs [9]. And this local wisdom arises through a process of internalization that is long and lasts for generations as a result of interactions between humans and their environment [10].Local wisdom is the expression of the tribe or ethnicity that produce specific works [11]. Such works can be a rule, law, or dieksprsikan through behavior and art [12]. Another opinion said that local wisdom includes values, norms, beliefs, ethics, customs, and special rules [13].

The conclusion from above opinion is that local wisdom is a view and traditional knowledge that is a reference in behaving and has been practiced for generations to meet the needs and challenges in the life of people. Local wisdom functions and is meaningful are both beneficial to natural and human resources, preserving custom and culture, and being beneficial for life.

The study of local wisdom and disaster mitigation in traditional communities in Indonesia is actually seen in relation to natural resources and human resources. In traditional (local) human society and nature is a unity because both of them are created by the Almighty. Nature and humans are believed to have the same spirit. Nature can be friendly if humans treat wisely and vice versa will be angry if we destroy it [14].

This study aims to: 1) Identify the local wisdom of the Way Krui Sub-district community for landslide disaster mitigation; 2) Analyzing the adaptation strategy of the Way Krui Subdistrict society in the face of landslides.

\section{Method}

The location of this study was in Way Krui Sub-district, Pesisir Barat Regency, Lampung Province. 


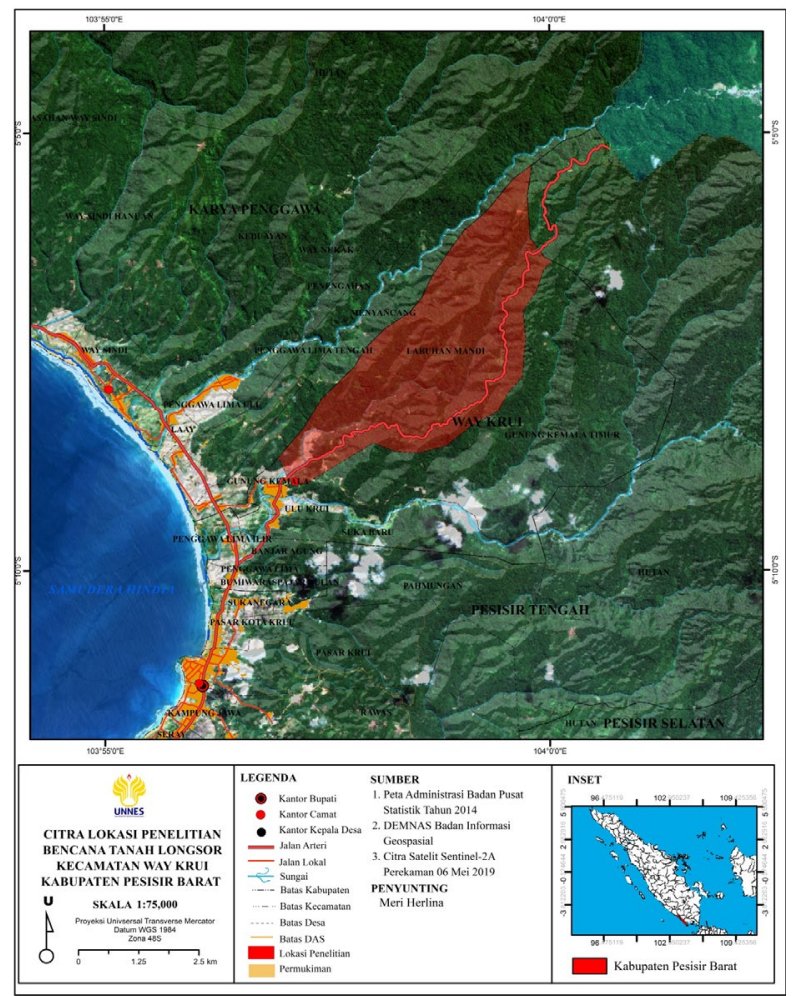

Figure 1. Research Location

This research approach uses a qualitative approach, with a phenomenological concept in which researchers express phenomena experienced by individuals naturally and to explain in detail the findings in the field. The focus of research is the form of local wisdom and the relationship of local wisdom to disaster mitigation. The informants of this study were the community and the chairman of the BPBD of Pesisir Barat District to explore the disaster and local wisdom of the community, while the supporting informants were community leaders and village leaders who were resilient to the disaster. The technique of collecting data uses techniques: observation, researchers observe directly the phenomena that exist in the field, 'interviews, carried out since March 18 for two weeks with communities experiencing disasters, BPBD leaders, community leaders and village leaders resilient to disasters; documentation to obtain secondary data such as research area profiles, disaster records and history of local wisdom. Validity techniques use data triangulation techniques that compare various types of data from different situations and triangulation of theories to provide a better understanding of data. Data analysis techniques are domain analysis, taxonomy, components and themes 


\section{Results and Discussion}

\subsection{Wisdom of Repong Damar}

Repong Damar is the local wisdom of the Pesisir Krui society in sustainable forest preservation. The management of repong damar in the West Coast area is one of the biodiversity conservation models carried out by the community ${ }^{[15]}$.

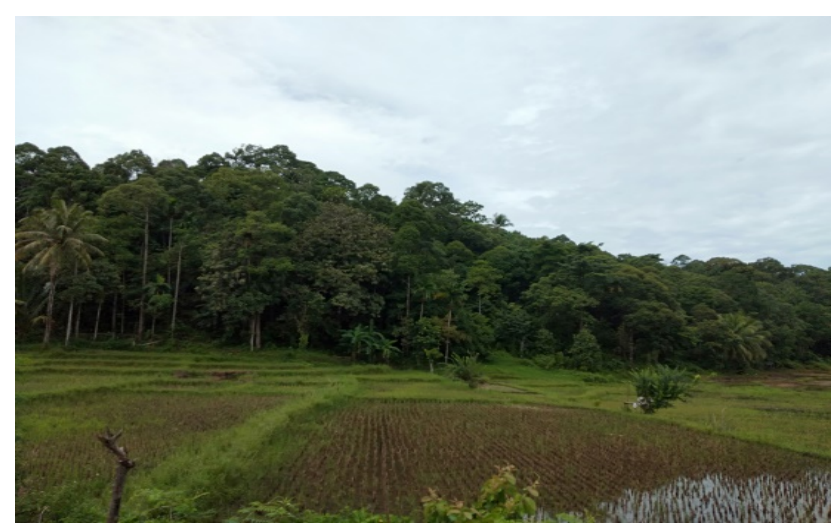

Figure 2. Repong Damar

Based on the results of the study, the people did not know for certain when the Repong Damar existed and how it originated, which they knew was Repong Damar, which had grown since the past and still exists because of the inheritance system, meaning it has been passed down for generations.

Another opinion says that the resin tree has been cultivated by the Pesisir Krui society since the Belanda era around 120 years ago and has become a part of the local community farming system through the cultivation of mixed forest trees (damar) with several agricultural commodities both seasonal crops (such as rice) and other annual crops (such as coffee, pepper, and fruits).

Repong Damar cultivation is done in hereditary and related to the local customary system. On that basis, the management of Repong Damar by the coastal community is a part of life closely related to economic and ecological values.

Table 1. The Benefits of Repong Damar

\begin{tabular}{cl}
\hline Benefits & \multicolumn{1}{c}{ Forms } \\
\hline Economics & Utilization of sap \\
& Utilization of wood \\
Ecology & Forest sustainability \\
& Landslide barrier \\
\hline & Source: Meri, May. 2019
\end{tabular}

Economically, damar tree is utilized from the rubber yield and the wood yield. Sap of damar has economic value because the benefits can be used as a base material for the manufacture of paints, dyes, ink, cosmetics, resin, wax and so forth. Damar Repong began to 
be utilized by the results after at least 20 years old. Under normal growth conditions or not disturbed by pests, whereas the wood from plant of damar is very beneficial for life like to build a house ${ }^{[16]}$. Both products of the damar can later increase food security for the surrounding society.

Table 2. How to preserve Repong Damar

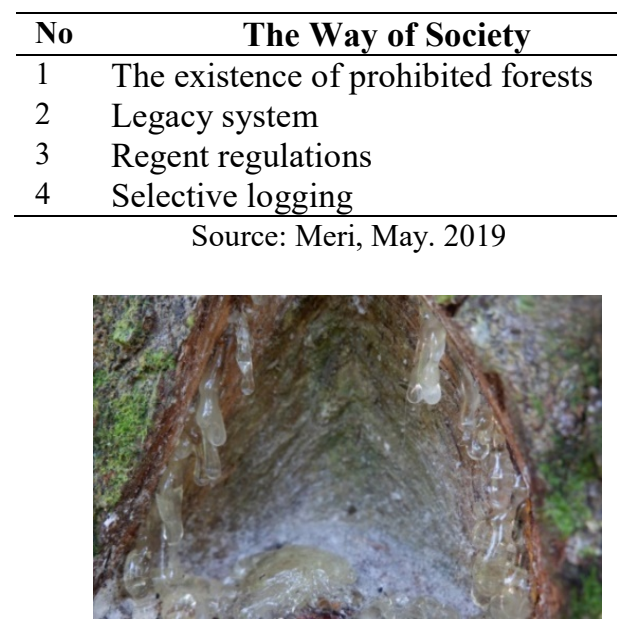

Figure 3. Economic Benefit of Damar Sap

Source: World of Indra and Onan

Ecologically, Repong Damar contributes to the preservation of the surrounding environment, and Repong Damar serves to preserve the preservation of forests to maintain natural balance including natural balance so as not to occur due to disaster because the roots of hard crops such as damar trees are able to hold the soil to prevent landslides.

The people of Pesisir Barat Regency, especially the people who live relying on damar trees, have their own ways to preserve Repong Damar, which is by the existence of prohibited forests, anyone who cuts down the forest excessively is believed will suffer. The values and norms that have existed for a long time related to the management of Repong Damar are indeed in accordance with the needs of society, which in the end now become a customs or habit that is carried out by the society.

The regions of Way Krui Sub-district, especially in Labuhan Mandi Village, are divided into several areas based on the ownership Repong Damar, where the first to the fifth area is privately owned by the people and not affected by the sanctions if cutting damar trees. But the sixth area to twelfth was a forest of people but enter into a protected forest areas, in which the people can utilize dammar sap and when the tree is cut down, it must be licensed by society leaders or local peratin with the right reasons. If the society violates this, then the person who violates will receive punishment in the form of reforestation or even imprisoned accordance to the mistake made.

The preservation of Repong Damar is not sufficient with the existence of customary law or government law, but what is equally important is how the society provides understanding to the younger generation not to damage Repong Damar as a source of life for the society. The message means that the society must maintain Repong Damar if they do not want to live miserably. 


\subsection{Community Adaptation Strategies}

Adaptation is a factor that related to the ability to respond to changes occur ${ }^{[17]}$. Adaptation is a public response to environmental change ${ }^{[18]}$. Regarding to adaptation, the adaptation in this study is physical and social adaptation.

Table 3. Adaptation to landslide

\begin{tabular}{ll}
\hline Adaptation & Form \\
\hline Physical & $\begin{array}{l}\text { Preservation of Repong Damar } \\
\text { Resettlement }\end{array}$ \\
& Embankment construction \\
\hline Social & $\begin{array}{l}\text { The existence of mutual } \\
\text { cooperation }\end{array}$ \\
\hline & Source: Meri, May. 2019
\end{tabular}

The physical adaptation, which is done by the society is the reforestation which is done by the society when there are trees being cut down, this is done by the society because this damar tree is a source of life for the people. So when the trees are cut down and not replaced, their source of life will also disappear.

The second physical adaptation and what the government does are evacuating a disasteraffected society by providing assistance to move houses to safer places. The most severe disaster in Labuhan Mandi Village in Way Krui Sub-district was during the disaster in 2002. At the time of the disaster caused 16 houses were hit by a landslide and were severely damaged and caused 11 causalities and one person has not yet been found.

The third physical adaptation is the construction of dikes to cover rock cliffs or slopes. This can help to minimize the occurrence of aftershocks because the land will be held back by the embankment.

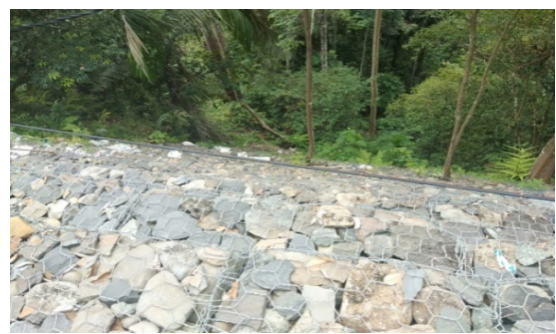

Figure 4. Landslide Mitigation Efforts at Way Krui

Source: Photo of Meri, March. 2019

Social adaptation, Social adaptation by the community is an improvement or adjustment to public facilities or social facilities. The public facilities that were affected when the landslide occurred were roads which were covered by mudslide material so that the traffic route from Pesisir Barat Regency to Liwa West Lampung Regency experiencing congestion. Another facility affected by the landslide was the collapse of electricity poles caused by the fall of trees. In this disaster management the society together with the $B P B D$ carried out road cleaning up and removing fallen trees, and as well as establish the electricity poles again but in different places, so that the same incident did not happen again. 
After several adaptation strategies carried out by the society, of course people have hope that landslide disasters do not happen again. The following are presented in table 4 .

Table 4. Community expectations

\begin{tabular}{ll}
\hline Hope & Form of Hope \\
\hline Society & $\begin{array}{l}\text { Environmentally conscious } \\
\text { Do not build houses in areas } \\
\text { that prone to landslide }\end{array}$ \\
\hline Government & Regular socialization \\
\hline \multicolumn{2}{c}{ Source: Meri, May. 2019}
\end{tabular}

\subsection{Analysis of Repong Damar for Landslide Mitigation}

Damar tree has several roles in preventing land movements or landslides, there are three roles of damar trees, namely the role of canopy intersection, root and evapotranspiration:

The first role, the vegetation begins with the canopy role of storing water, thereby reducing the amount of rainwater that reaches the ground.

The second role, the large root will have the grip of the land which can reduce the possibility of soil movement and increase the shear strength of the soil.

The third role, evapotranspiration. In the zones that have high rainfall intensity, the evapotranspiration process plays a role in reducing the saturation of the soil so that there is no accumulation of water in the impermeable layer which will actually be a slip material in shallow landslide.

Based on the above opinion, it has been proven that damar trees have an important role in resisting land movement when a landslide will occur. This is reinforced by the reason that the roots have functions such as strengthening the soil, provide support to the upper soil thereby reducing erosion.

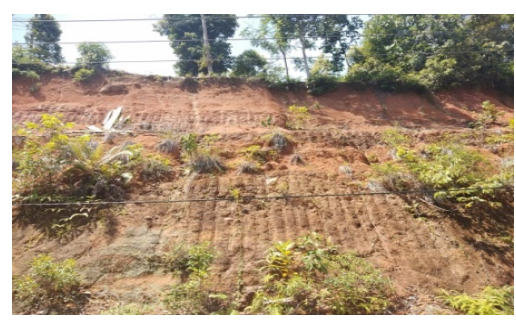

Figure 5. Landslide Prone Areas in Way Krui Sub-district Source: Photo of Meri, March. 2019

\section{Conclusion}

Local wisdom of the society to manage Repong Damar as a form of landslide mitigation is the existence of prohibited forests. So if the society destroys Repong Damar it is believed that it will be miserable and will get a bad disaster. The adaptation strategy carried out by the community is physical and social adaptation. Physical adaptation through resettlement, repairs to public facilities affected by landslides and construction of dikes to 
prevent subsequent landslides and of course the preservation of Repong damar by reforestation. The social adaptation of the society is by the existence of society cooperation in restoring the original condition as previously. 


\section{References}

[1] Magdalena, M. (2013). Peran Hukum Adat dalam Pengelolaan dan Perlindungan Hutan di Desa Sesaot, Nusa Tenggara Barat dan Desa Setulang, Kalimantan Timur. Jurnal Penelitian Sosial dan Ekonomi Kehutanan, 10(2).

[2] Basmar, A. 2018. Arahan Pengembangan Kawasan Usaha Agro Terpadu Berbasis Komoditas Kelapa di Kabupaten Lampung Barat. Bogor: Sekolah Pasca Sarjana IPB.

[3] Mubekti, M. (2011). Mitigasi Daerah Rawan Tanah Longsor Menggunakan Teknik Pemodelan Sistem Informasi Geografis; Studi Kasus: Kecamatan Sumedang Utara dan Sumedang Selatan. Jurnal Teknologi Lingkungan, 9(2).

[4] Arifianti, Y. (2011). Buku mengenal tanah longsor Sebagai media pembelajaran bencana sejak dini. Bulletin Vulkanologi dan Bencana Geologi, 6(3), 17-24.

[5] Setyowati, D. L. (2010). Erosi dan Mitigasi Bencana.

[6] Hungr, O. (2018). Some methods of landslide hazard intensity mapping. In Landslide risk assessment (pp. 215-226). Routledge.

[7] Juhadi, J., Hidayah, I., \& Nugraha, S. B. (2018). Pendidikan Kebencanaan Untuk Anak Usia Dini Dengan Wahana Bermain Taman Eling-Waspada-Siaga (Ews). Jurnal Pengabdian Kepada Masyarakat, 24(2), 655-661.

[8] Juhadi, Kurniasari, Nia. (2016). Pola Perilaku Myarakat Dalam Pengurangan Resiko Bencana Tanah Longsor di Kecamatan Banjarwangu Kabupaten Banjar Negara Jawa Tengah. Jurnal Geografi, 13 (2), 216-224

[9] Ariyanto, A., Rachman, I., \& Toknok, B. (2014). Kearifan Masyarakat Lokal dalam Pengelolaan Hutan di Desa Rano Kecamatan Balaesang Tanjung Kabupaten Donggala. Jurnal Warta Rimba, 2(2).

[10] Setyowati, D. L., Juhadi, J., \& Kiptida'iyah, U. (2017). Konservasi Mata Air Senjoyo Melalui Peran Serta Masyarakat Dalam Melestarikan Nilai Kearifan Lokal. Indonesian Journal Of Conservation, 6(1).

[11] Meliono, Irmayanti. 2011. Understanding the Nusantara Thought and Local Wisdom as an Aspect of the Indonesian Education. Tawarikh: International Journal for Historical Studies, 2(2).

[12] Gunawan Rudy, Eko Digdoyo, \& Aryo Subarkah. 2014. Budaya Kearifan Lokal Dalam Tata Kelola Dan Pengembangan Lingkungan Kota Sejarah Dan Budaya, Tahun Kedelapan, Nomor 2. 2014.

[13] Sriyono, A. Suroso. Setyowati, D.L. (2012). Identifikasi Kawasan Rawan Bencana Longsor Kecamatan Banyubiru, Kabupaten Semarang (Doctoral dissertation, Universitas Negeri Semarang).

[14] Permana, C. E., Nasution, I. P., \& Gunawijaya, J. (2012). Kearifan lokal tentang mitigasi bencana pada masyarakat Baduy. Hubs-Asia, 10(1).

[15] Juhadi, J. (2013). Sistem Pertanian Kebun Campuran Berkelanjutan Berbasis Teknologi Tradisional Studi Kasus pada Masyarakat Krui Lampung Barat. In Forum Ilmu Sosial (Vol. 40, No. 2).

[16] Putri AHM dan Wulandari, C. (2015). Potensi Penyerapan Karbon Pada Tegakan Damar Mata Kucing di Pekon Gunung Kemala Krui Lampung Barat. Jurnal Syilva Lestari. Vol. 3.

[17] Kumalasari, N. R. (2014). Kapasitas Adaptasi Terhadap Kerentanan dan Bencana Perubahan Iklim di Tambak Lorok Kelurahan Tanjung Mas Semarang. Jurnal Pembangunan Wilayah \& Kota, 10(4), 476-487. 
[18] Clarvis dan Allan. 2013. Adaptive Capacity in a Chilean Context: A questionable model for latin America. Environtmental Science, Vol xxx page 13 